\title{
Response of Sweet Corn to Microbial Inoculation by Gluconacetobacter diazotrophicus
}

\author{
N. A. Bidarkar and D. R. Murumkar \\ Department of Plant Pathology and Agril, Microbiology, Post Graduate Institute, Mahatma \\ Phule Krishi Vidyapeeth, Rahuri - 413 722, Dist.-Ahmednagar, Maharashtra, India \\ *Corresponding author
}

\section{A B S T R A C T}

\begin{tabular}{|l|}
\hline Ke y w or d s \\
$\begin{array}{l}\text { Gluconacetobacter } \\
\text { diazotrophicus, } \\
\text { Growth parameters, } \\
\text { N uptake, Sweet } \\
\text { corn yield }\end{array}$ \\
\hline Article Info \\
\hline $\begin{array}{l}\text { Accepted: } \\
17 \text { June } 2020 \\
\text { Available Online: } \\
10 \text { July } 2020\end{array}$ \\
\hline \hline
\end{tabular}

A field experiment was conducted to study the effect of seed inoculation of Gluconacetobacter diazotrophicus on growth parameters, nutrient uptake and yield of sweet corn. Among different inoculation treatments, seed inoculation with $G$. diazotrophicus (Phule Madhu strain) $+50 \%$ recommended dose of nitrogen was found to be the most effective as it recorded significantly highest germination $(94.33 \%)$ and plant vigour index (3249.32) at 15 days after sowing; significantly highest plant height at 30 and 60 days after sowing and at harvest stage the crop $(53.56 \mathrm{~cm}, 144.12 \mathrm{~cm}$ and $155.74 \mathrm{~cm}$, respectively); significantly highest root length $(22.96 \mathrm{~cm}$ and $26.79 \mathrm{~cm})$ and dry matter production (37.29 $\mathrm{q} \mathrm{ha}^{-1}$ and $74.31 \mathrm{q} \mathrm{ha}^{-1}$ ) at flowering and harvest stage of the crop; significantly highest green cob yield $\left(287.57 \mathrm{q} \mathrm{ha}^{-1}\right)$ and green fodder yield (555.01 $\left.\mathrm{q} \mathrm{ha}^{-1}\right)$ at 80 days after sowing; significantly highest $G$. diazotrophicus population at flowering $\left(6.75 \times 10^{6} \mathrm{~g}^{-1}\right.$ fresh weight of shoot) and at harvest $\left(5.68 \times 10^{6} \mathrm{~g}^{-1}\right.$ fresh weight of shoot $)$ stage of the crop; significantly highest nitrogen uptake (488.87 $\left.\mathrm{kg} \mathrm{ha}^{-1}\right)$ and sugar content ( $18.19 \%$ brix) of sweet corn grain, however it was as statistically at par with the treatment of seed inoculation with G. diazotrophicus (MPKV strain) + 50\% recommended dose of N and $100 \%$ recommended dose of $\mathrm{N}$ without $G$. diazotrophicus for growth parameters, nutrient uptake, yield and sugar content of sweet corn grains. The results indicated saving of $50 \%$ chemical nitrogen fertilizer to sweet corn.

\section{Introduction}

Sweet corn (Zea mays L. Saccharata) cv. Phule Madhu is a variety of maize with high sugar content. Sweet corn is a naturally occurring recessive mutation in the genes which control conversion of sugar to starch inside the endosperm of the corn kernel. It is harvested at milky stage and eaten as a vegetable, rather than a grain. The area under maize crop in India is reported to be 9.43 million ha. with an annual production of 24.35 million tones. It can be taken throughout three season in India but in Maharashtra particularly taken both in kharif and rabi season.

Gluconacetobacter diazotrophicus is an endophytic bacterium first isolated from the sugarcane growing regions of Brazil 
(Cavalcante and Dobereiner, 1988). It is found to live freely in the intercellular spaces of roots, stems and leaves of the sugarcane plant, actively fixes atmospheric $\mathrm{N}$ and provides plants with the needed nitrogen (Boddey et al., 1991). Moreover, the colonization of nitrogen fixing bacterium $G$. diazotrophicus in corn plants has been reported by Tian et al., (2009). Furthermore, Riggs et al., (2001) reported that maize productivity has been enhanced by inoculation with endophytic diazotrophic bacteria. It has also been reported that besides $\mathrm{N}$ fixation, all the strains of $G$. diazotrophicus produced indole acetic acid in a culture medium supplemented with tryptophan in the range of 0.14 to $2.42 \mu \mathrm{g} \mathrm{ml}{ }^{-1}$ (FuentezRamirez et al., 1993 and Bastian et al., 1998). Furthermore, it has been reported its ability to solubilize inorganic phosphates from the soil and make available $\mathrm{P}$ for the inoculated crops (Crespo et al., 2011). Sweet corn requires 120 $\mathrm{kg} \mathrm{N}, 60 \mathrm{~kg} \mathrm{P}_{2} \mathrm{O}_{5}$ and $40 \mathrm{~kg} \mathrm{~K}_{2} \mathrm{O}$ for its growth. Due to increase in cost of chemical nitrogenous fertilizer, the marginal farmer cannot afford the fertilizer to the crop with the recommended doses. Therefore, biological nitrogen fixation through microorganisms has been found very economical and advantages (Stephan et al., 1991).

Keeping this in view, in the present investigation an attempt was made to evaluate the effect of Gluconacetobacter diazotrophicus on growth, yield and nitrogen uptake in sweet corn.

\section{Materials and Methods}

\section{Isolation of Gluconacetobacter diazotrophicus from Root Sample of Sweet Corn}

Since Gluconacetobacter diazotrophicus is an endophyte, the isolation was done using root samples of sweet corn. The plants were uprooted and the root portion was separated and washed with tap water. The roots were washed with sterile distilled water and surface sterilized for $5 \mathrm{~min}$ with $5 \%$ sodium hypochloride $(\mathrm{NaOCl})$ and then washed five times with sterile distilled water. The surface sterilized root samples were weighed and homogenized in a sterile sucrose solution (1\%) using a sterile pestle and mortar. Aliquots $(500 \mathrm{ml})$ were inoculated in the tubes containing semisolid LGIP medium (Cavalcante and Dobereiner, 1988) and incubated at $30^{\circ} \mathrm{C}$ for 4-6 days. Yellowish bacterial growth from the tubes was streaked onto LGIP plates (Cavalcante and Dobereiner, 1988) and incubated at $30^{\circ} \mathrm{C}$ for $6-7$ days.

\section{Morphological and Cultural Characterization of the Isolate}

The isolate was examined for cell morphology and gram reaction as per the standard procedures given by Cappuccino and Sherman (1987). The colony morphology of the isolate was compared with Gluconacetobacter diazotrophicus MPKV strain.

\section{Biochemical and Physiological Characterization}

The isolate was further characterized using a series of biochemical tests viz., gelatin liquefaction, catalase test, oxidase test, growth on carbon source, growth at various concentrations of sugar and growth at various temperatures according to Dong et al., (1995) and Muthukumarasamy et al., (1999).

\section{Utilization of different carbon sources by G. diazotrophicus}

The culture medium was amended with different carbon sources viz., Glucose, sucrose, ethanol and mannitol and autoclaved. Sterilized petriplates were poured with 15-20 
$\mathrm{ml}$ medium with different carbon sources and allowed to solidify. After solidification, $10 \mu \mathrm{l}$ of $24 \mathrm{hrs}$ old culture of the test organism was spotted on plates with each carbon source. The plates were incubated for $48 \mathrm{hrs}$ at $28 \pm$ $2^{\circ} \mathrm{C}$ and the ability of the isolate to grow on different carbon sources was noted.

\section{Nitrogen Fixing Ability of the Isolate}

The 48 hour old culture of freshly isolated $G$. diazotrophicus strain was inoculated to $5 \mathrm{ml}$ of $\mathrm{N}$ free semisolid broth of LGIP medium. It was incubated for $48 \mathrm{hrs}$ and $1 \mathrm{ml}$ of this broth was inoculated to $50 \mathrm{ml}$ semisolid LGIP medium.

Then it was incubated for 15 days. $10 \mathrm{ml}$ of this culture was used for $\mathrm{N}$ estimation by following the standard procedure of Microkjeldhal technique (Reis et al., 1994).

The formula for $\mathrm{N}_{2}$ estimation is:

$$
\begin{aligned}
& \mathrm{ml} \text { of } \mathrm{H}_{2} \mathrm{SO}_{4} \text { in the sample } \mathrm{x} \text { Normality of } \mathrm{H}_{2} \mathrm{SO}_{4} \times 14.01 \\
& \mathrm{~N}_{2}(\mathrm{mg} g)=
\end{aligned}
$$

\section{Field Experiment}

A field experiment was conducted during kharif 2018 at the Instructional Research Farm, Central Campus, Post Graduate Institute, Mahatma Phule Krishi Vidyapeeth, Rahuri to study the effect of seed inoculation of $G$. diazotrophicus on growth parameters, nutrient uptake and yield of sweet corn. The sweet corn hybrid Phule Madhu was used as a test crop. The seeds of sweet corn (var. Phule Madhu) were treated with $G$. diazotrophicus by following slurry method of seed inoculation and inoculated seeds were dried in shade before sowing. The experiment was laid out in randomized block design with three replications and seven treatments.

\section{Treatment details}

The sweet corn seeds were inoculated with Gluconacetobacter diazotrophicus before sowing as follows.

$\mathrm{T}_{1}$ : G. diazotrophicus (Phule Madhu strain) alone

$\mathrm{T}_{2}$ : G. diazotrophicus (Phule Madhu strain) + $50 \%$ recommended dose of $\mathrm{N}$

$\mathrm{T}_{3}$ : G. diazotrophicus (Phule Madhu strain) + $75 \%$ recommended dose of $\mathrm{N}$

$\mathrm{T}_{4}$ : G. diazotrophicus (MPKV strain) $+50 \%$ recommended dose of $\mathrm{N}$

$\mathrm{T}_{5}$ : G. diazotrophicus (MPKV strain) $+75 \%$ recommended dose of $\mathrm{N}$

$\mathrm{T}_{6}: 100 \%$ recommended dose of $\mathrm{N}$ without $G$.

diazotrophicus

$\mathrm{T}_{7}$ : Uninoculated control

Note: $\mathrm{P}_{2} \mathrm{O}_{5} @ 60 \mathrm{~kg} \mathrm{ha}^{-1}$ and $\mathrm{K}_{2} \mathrm{O} @ 40 \mathrm{~kg} \mathrm{ha}^{-}$ ${ }^{1}$ (as per recommendation) was applied to all the treatments except uninoculated control.

The observations on germination (\%), plant vigour index, plant height $(\mathrm{cm})$ at 30, 60 days after sowing and at harvest stage (80 DAS), root length $(\mathrm{cm})$ at flowering $(40$ DAS) and harvest stage (80 DAS), dry matter production $\left(\mathrm{kg} \mathrm{ha}^{-1}\right)$ at flowering (40 DAS) and harvest stage (80 DAS), green cob yield ( $\left.\mathrm{q} \mathrm{ha}^{-1}\right)$ and green fodder yield $\left(\mathrm{q} \mathrm{ha} \mathrm{ha}^{-1}\right)$ at milky stage (80 DAS) of the sweet corn were recorded.

\section{Plant Vigour index}

Plant vigour index was computed at 15 days after sowing using the procedure suggested by Abdul Baki and Anderson (1973):

Plant vigour index $=$ Germination $\% \mathrm{x}$ [shoot length $(\mathrm{cm})+$ root length $(\mathrm{cm})]$

\section{Estimation of Nitrogen}

Nitrogen content of plant was estimated by following Modified Kjeldahl's process as 
described by Jackson (1973) and accordingly $\mathrm{N}$ uptake $\left(\mathrm{kg} \mathrm{ha}^{-1}\right)$ was estimated as $\mathrm{N} \% \mathrm{x}$ total dry matter yield $\left(\mathrm{kg} \mathrm{ha}^{-1}\right) / 100$.

\section{Brix reading using hand refractometer}

The sugar content of sweet corn grain at milky stage was estimated as Brix (\%) using hand refractometer.

Enumeration of microbial population of $G$. diazotrophicus in shoot

The population of $G$. diazotrophicus in shoot of sweet corn plant was enumerated at 30 and 60 days after sowing and at harvesting of the crop by following serial dilution and pour plate technique (Aneja, 2003). The LGIP medium was used for enumeration of $G$. diazotrophicus population. The population was expressed as cfu $\mathrm{g}^{-1}$ plant sample.

\section{Statistical Analysis}

The data recorded on various parameters were subjected to statistical analysis by following standard method of analysis of variance. The level of significance used in ' $F$ ' and ' $t$ ' tests was $P=0.05$. Critical difference $(C D)$ values were calculated where the ' $F$ ' test was found significant (Panse and Sukhatme, 1985).

\section{Results and Discussion}

\section{Biochemical Characterization of Endophytic Bacterial Isolate}

The isolation of endophytic nitrogen fixing bacterium Gluconacetobacter diazotrophicus from root sample of sweet corn (var. Phule Madhu) was done using semisolid LGIP medium. The endophytic bacterial isolate was tested for different biochemical characters viz., gram staining, motility, gelatin liquefaction, catalase test, oxidase test, growth on carbon sources, growth at various concentrations of sugar and growth at various temperatures (Table 1). The cells of endophytic bacterial isolate were motile, rod shape and gram negative in reaction. The endophytic bacterial isolate was positive for catalase and oxidase test, but was negative for gelatin hydrolysis. Glucose, sucrose, ethanol and mannitol were used as a sole carbon source for growth by the endophytic bacterial isolate. Moreover, the growth of endophytic bacterial isolate was positive at various concentrations $(5,10,20$ and $30 \%)$ of sugar. In addition, the growth of endophytic bacterial isolate was positive at $28^{\circ} \mathrm{C}, 32^{\circ} \mathrm{C}$, and $37^{\circ} \mathrm{C}$ temperature, but was negative at $4^{\circ} \mathrm{C}$. Based on biochemical and physiological characterization, the endophytic bacterial isolate was identified as Gluconacetobacter diazotrophicus. The results of the present investigation are in conformity with results of Hema and Savalgi (2017) that isolated nitrogen fixing endpohytic bacterium $G$. diazotrophicus from root tissue of sugarcane, maize, pineapple and carrot and further characterized these isolates biochemically for specific characters of $G$. diazotrophicus according to Burgey's Manual of Systematic Bacteriology.

\section{Nitrogen Fixing Ability of G. diazotrophicus Isolate}

The endophytic bacterial isolate (Phule Madhu strain) alongwith MPKV strain were subjected to know the nitrogen fixation by Microkjeldhal method (Table 2). The strain from sweet corn fixed highest amount of nitrogen $(148.65 \mu \mathrm{g}$ of nitrogen/mg of carbon used) than MPKV strain (121.84 $\mu \mathrm{g}$ of nitrogen/mg of carbon used). The results of the present investigation are in agreement with results of Hema and Savalgi (2017) who reported that endophytic bacterial isolate $G$. diazotrophicus from maize GdM5 fixed about $42 \mu \mathrm{g}$ of nitrogen/mg of carbon used which was equivalent to that of reference culture of 
G. diazotrophicus (MTCC1224), whereas the isolate from sugarcane GdS25 fixed highest amount of nitrogen than other strains i.e. $147 \mu \mathrm{g}$ of nitrogen/mg of carbon used.

Table.1 Selective biochemical tests of Gluconacetobacter diazotrophicus isolate of sweet corn (Phule Madhu strain)

\begin{tabular}{|c|c|c|}
\hline $\begin{array}{l}\text { Sr. } \\
\text { No. }\end{array}$ & Biochemical tests & $\begin{array}{l}\text { Gluconacetobacter diazotrophicus } \\
\text { isolate of sweet corn } \\
\text { (Phule Madhu strain) }\end{array}$ \\
\hline 1. & Cell shape & Rod shape \\
\hline 2. & Gram reaction & Gram negative \\
\hline 3. & Motility & + \\
\hline 4. & Gelatin liquefaction & - \\
\hline 5. & Catalase activity & + \\
\hline 6. & Oxidation of ethanol & + \\
\hline \multirow[t]{5}{*}{7.} & Growth on carbon sources & \\
\hline & a) Glucose & + \\
\hline & b) Sucrose & + \\
\hline & c) Ethanol & + \\
\hline & d) Mannitol & + \\
\hline \multirow[t]{5}{*}{8.} & Growth at various concentration of sugar & \\
\hline & a) $5 \%$ & + \\
\hline & b) $10 \%$ & + \\
\hline & c) $20 \%$ & + \\
\hline & d) $30 \%$ & + \\
\hline \multirow[t]{5}{*}{9.} & Growth at various temperatures & \\
\hline & a) $4 \mathrm{oC}$ & - \\
\hline & b) $28 \mathrm{oC}$ & + \\
\hline & c) $320 \mathrm{C}$ & + \\
\hline & d) $37 \mathrm{oC}$ & + \\
\hline
\end{tabular}

Table.2 Nitrogen fixing ability of Gluconacetobacter diazotrophicus isolate of sweet corn by Microkjeldhal method

\begin{tabular}{|c|c|c|}
\hline $\begin{array}{l}\text { Sr. } \\
\text { No. }\end{array}$ & Isolate & $\begin{array}{c}\text { Nitrogen fixing ability } \\
\text { ( } \mathrm{gg} \text { of Nitrogen/mg of Carbon) }\end{array}$ \\
\hline 1. & $\begin{array}{l}\text { Gluconacetobacter diazotrophicus } \\
\text { (Phule Madhu strain) }\end{array}$ & 148.65 \\
\hline 2. & $\begin{array}{l}\text { Gluconacetobacter diazotrophicus } \\
\text { (MPKV strain) }\end{array}$ & 121.84 \\
\hline
\end{tabular}


Table.3 Effect of inoculation of G. diazotrophicus on growth parameters of sweet corn

\begin{tabular}{|c|c|c|c|c|c|c|c|c|c|c|}
\hline \multirow[t]{2}{*}{$\begin{array}{l}\text { Tr. } \\
\text { No }\end{array}$} & \multirow[t]{2}{*}{ Treatment details } & \multirow[t]{2}{*}{$\begin{array}{l}\text { Germinatio } \\
\text { n }(\%)\end{array}$} & \multirow[t]{2}{*}{$\begin{array}{l}\text { Plant } \\
\text { vigour } \\
\text { index }\end{array}$} & \multicolumn{3}{|c|}{ Plant height (cm) } & \multicolumn{2}{|c|}{ Root length (cm) } & \multicolumn{2}{|c|}{$\begin{array}{l}\text { Dry matter } \\
\text { production } \\
\qquad\left(\mathbf{q} \mathbf{h a}^{-1}\right)\end{array}$} \\
\hline & & & & $30 \mathrm{DAS}$ & 60 DAS & $\begin{array}{c}\text { Harvest } \\
(80 \text { DAS })\end{array}$ & $\begin{array}{l}\text { Flowering } \\
(40 \text { DAS) }\end{array}$ & $\begin{array}{l}\text { Harvest } \\
(80 \text { DAS })\end{array}$ & $\begin{array}{l}\text { Flowering } \\
(40 \text { DAS) }\end{array}$ & $\begin{array}{l}\text { Harvest } \\
\text { (80 DAS) }\end{array}$ \\
\hline $\mathbf{T}_{1}$ & $\begin{array}{l}\text { G. diazotrophicus (Phule Madhu } \\
\text { strain) alone }\end{array}$ & 87.67 & 2670.24 & 47.41 & 137.93 & 145.49 & 20.32 & 24.15 & 34.65 & 69.35 \\
\hline $\mathbf{T}_{2}$ & $\begin{array}{l}\text { G. diazotrophicus (Phule Madhu } \\
\text { strain) }+50 \% \text { recommended N }\end{array}$ & 94.33 & 3249.32 & 53.56 & 144.12 & 155.74 & 22.96 & 26.79 & 37.29 & 74.31 \\
\hline $\mathbf{T}_{\mathbf{3}}$ & $\begin{array}{l}\text { G. diazotrophicus (Phule Madhu } \\
\text { strain) }+75 \% \text { recommended N }\end{array}$ & 90.33 & 2833.94 & 48.45 & 138.93 & 148.05 & 20.93 & 24.58 & 35.30 & 70.46 \\
\hline $\mathbf{T}_{4}$ & $\begin{array}{l}\text { G. diazotrophicus (MPKV strain) } \\
+50 \% \text { recommended N }\end{array}$ & 91.67 & 3028.68 & 51.38 & 141.37 & 152.27 & 22.02 & 25.85 & 36.35 & 72.55 \\
\hline $\mathbf{T}_{5}$ & $\begin{array}{l}\text { G. diazotrophicus (MPKV strain) } \\
+75 \% \text { recommended N }\end{array}$ & 89.33 & 2652.21 & 46.21 & 137.94 & 147.04 & 19.80 & 23.63 & 34.13 & 68.38 \\
\hline $\mathbf{T}_{6}$ & $\begin{array}{l}100 \% \text { recommended } \mathrm{N} \text { without } \\
\text { G. diazotrophicus }\end{array}$ & 90.67 & 2921.18 & 50.08 & 140.67 & 151.60 & 21.46 & 25.29 & 35.79 & 71.50 \\
\hline \multirow[t]{4}{*}{$\mathbf{T}_{7}$} & Uninoculated control & 83.33 & 2202.36 & 41.10 & 131.11 & 140.78 & 17.61 & 21.44 & 31.94 & 64.26 \\
\hline & S.E. & 1.32 & 107.04 & 1.53 & 1.35 & 2.03 & 0.67 & 0.73 & 0.67 & 1.25 \\
\hline & C.D.at $5 \%$ & 4.07 & 329.83 & 4.72 & 4.16 & 6.24 & 2.05 & 2.25 & 2.05 & 3.86 \\
\hline & C.V. & 2.55 & 6.64 & 5.50 & 1.68 & 2.36 & 5.57 & 5.15 & 3.29 & 3.10 \\
\hline
\end{tabular}

G. diazotrophicus $=$ Gluconacetobacter diazotrophicus

DAS $=$ Days after sowing 
Table.4 Effect of inoculation of G. diazotrophicus on yield, nutrient uptake and population of G. diazotrophicus in sweet corn shoot

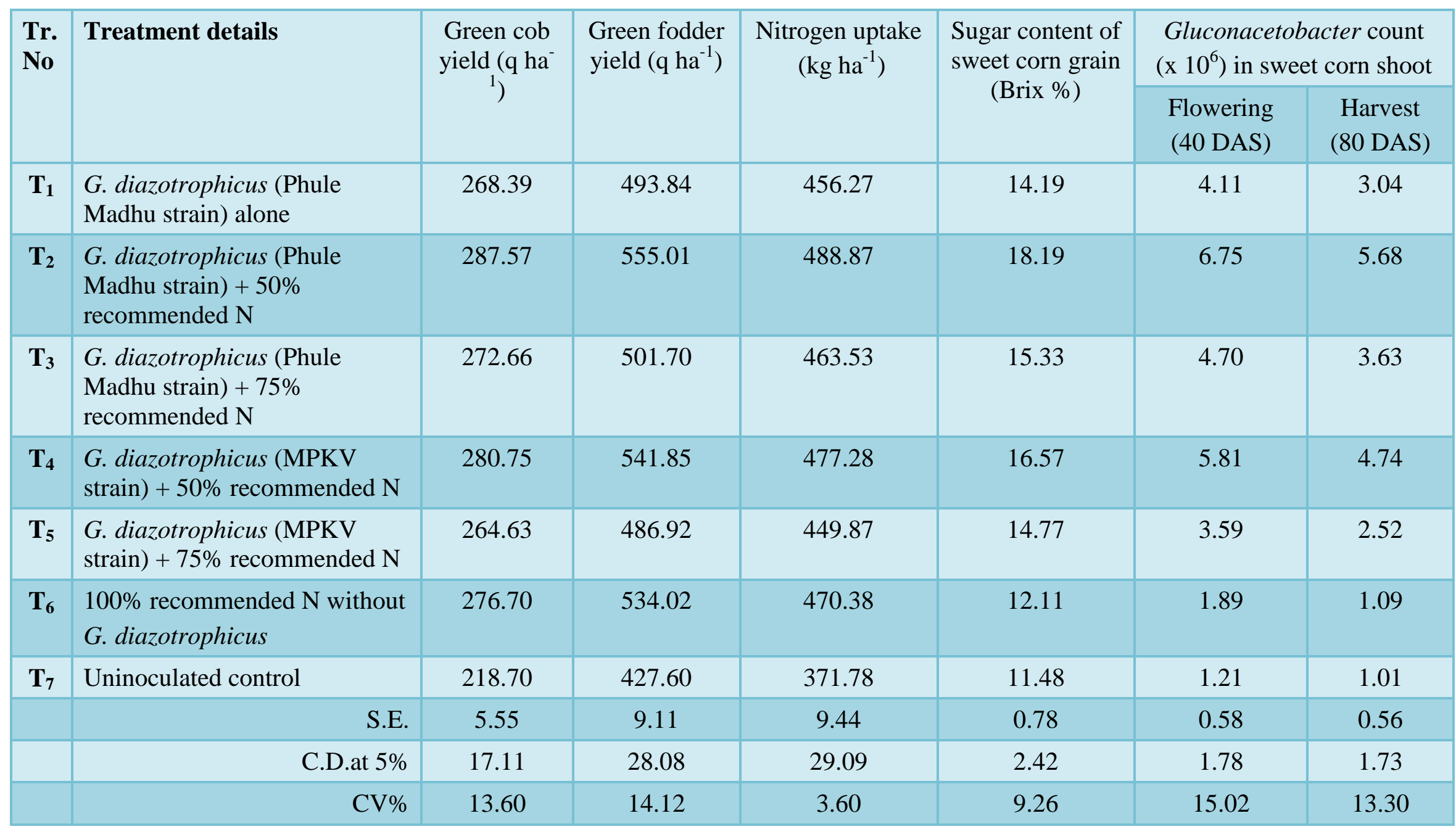


Inoculation Effect of $G$. diazotrophicus on Growth Parameters and Yield of Sweet corn

The results in respect of growth and yield attributing characters of sweet corn are presented in (Table 3 and 4). It was revealed from the data that all the growth parameters and green cob yield and fodder yield differences were significant due to seed inoculation with Gluconacetobacter diazotrophicus. Among different inoculation treatments, $\mathrm{T}_{2}$ i.e. seed inoculation with $G$. diazotrophicus (Phule Madhu strain) $+50 \%$ recommended dose of nitrogen was found to be the most effective as it recorded significantly highest germination $(94.33 \%)$ and plant vigour index (3249.32) at 15 days after sowing; significantly highest plant height at 30 and 60 days after sowing and at harvest stage the crop $(53.56 \mathrm{~cm}, 144.12 \mathrm{~cm}$ and $155.74 \mathrm{~cm}$, respectively); significantly highest root length $(22.96 \mathrm{~cm}$ and $26.79 \mathrm{~cm})$ and dry matter production $\left(37.29 \mathrm{q} \mathrm{ha}^{-1}\right.$ and $74.31 \mathrm{q} \mathrm{ha}^{-1}$ ) at flowering and harvest stage of the crop; significantly highest nitrogen uptake $\left(488.87 \mathrm{~kg} \mathrm{ha}^{-1}\right)$ and sugar content $(8.19 \%$ brix) of sweet corn grain and significantly highest green cob yield $\left(287.57 \mathrm{q} \mathrm{ha}^{-1}\right)$ and green fodder yield $\left(555.01 \mathrm{q} \mathrm{ha}^{-1}\right)$ at 80 days after sowing, however it was as statistically at par with the treatment $\mathrm{T}_{4}$ i.e. seed inoculation with G. diazotrophicus (MPKV strain)+ 50\% recommended dose of $\mathrm{N}$ and $\mathrm{T}_{6}$ i.e. $100 \%$ recommended dose of $\mathrm{N}$ without $G$. diazotrophicus for growth parameters, nutrient uptake, yield and sugar content of sweet corn grains. The results indicated saving of $50 \%$ chemical nitrogen fertilizer to sweet corn.

Results of the present investigation are in conformity with Murumkar et al., (2017), Partick et al., (2000), Pandey (2004) and Chauhan et al., (2010) who reported increased crop yield in different crops due to inoculation of G. diazotrophicus individually and in combination with $H$. seropedicae. Moreover, Indi et al., (2017) reported the enhancement in sugarcane yield to the tune of 20-22 t/ha and CCS yield by $3 \mathrm{t} / \mathrm{ha}$ with $50 \%$ reduction in the recommended dose of chemical nitrogen by use of G. diazotrophicus as set treatment before planting or spray the broth culture of $G$. diazotrophicus at 60 days after planting. Furthermore, Muthukumarasamy et al., (1994) reported 50 $\%$ reduction in $\mathrm{N}$ fertilizer with increase in crop productivity by 5-7 $\mathrm{t}$ acre ${ }^{-1}$ due to use of nitrogen fixing bacteria Acetobacter diazotrophicus, Azospirillum and Azotobacter as a biofertilizer for sugarcane. These results corroborate results of the present investigation that seed inoculation of $G$. diazotrophicus (Phule Madhu strain) saves $50 \%$ of the recommended dose of nitrogenous fertilizer with exuberant increase in crop productivity of sweet corn.

\section{Inoculation Effect of G. diazotrophicus on microbial population}

The results in respect of population of $G$. diazotrophicus in shoot of sweet corn plant at flowering (40 DAS) and harvest (80 DAS) stage as influenced by inoculation of $G$. diazotrophicus under graded levels of nitrogen are presented in Table 4. Among different inoculation treatments, $\mathrm{T}_{2}$ i.e. seed inoculation with $G$. diazotrophicus (Phule Madhu strain) $+50 \%$ recommended dose of nitrogen was found to be the most effective as it recorded significantly highest $G$. diazotrophicus population at flowering ( 6.75 $\mathrm{x} 10^{6} \mathrm{~g}^{-1}$ fresh weight of shoot) and at harvest $\left(5.68 \times 10^{6} \mathrm{~g}^{-1}\right.$ fresh weight of shoot) stage of the crop over rest of the treatments, however it was statistically at par with $\mathrm{T}_{4}$ i.e. $G$. diazotrophicus (MPKV strain) $+50 \%$ recommended dose of $\mathrm{N}$ for $G$. diazotrophicus population at flowering (5.81 $\mathrm{x} 10^{6} \mathrm{~g}^{-1}$ fresh weight of shoot) and at harvest 
(4.74 $\times 10^{6} \mathrm{~g}^{-1}$ fresh weight of shoot) stage of the crop. Different scientists have obtained varying results in regard to population of these diazotrophs. Murumkar et al., (2017) reported that sugarcane set inoculation with G. diazotrophicus @ $10 \mathrm{~kg}$ in 100 litwater/ha for $30 \mathrm{~min}$ before planting significantly improved the Gloconacetobacter population in cane at 10 months. Moreover, Navadkar (2015) reported that integrated inoculation of $G$. diazotrophicus and $H$. seropedicae to sweet corn seeds resulted in highest $G$. diazotrophicus and $H$. seropedicae population in shoot of sweet corn plant at flowering and harvest stage of the crop. Furthermore, Dobereiner et al., (2000) observed Acetobacter diazotrophicus in many sugarcane varieties and numbers were in the range of 103-107 in washed roots, 103-105 in surface sterilized roots, 103-106 in basal and apical stem; besides 104-107 in sugarcane trash. Similar results were reported by Fuentez et al., (1999) and Archna et al., (2008) in sugarcane and found that colonization of sugarcane by $A$. diazotrophicus was inhibited by high nitrogen fertilizer. Results of the present investigation are in conformity with the results of these scientists.

In conclusion from the present investigation it can be concluded that seed inoculation with Gluconacetobacter diazotrophicus $+50 \%$ recommended dose of nitrogen was found to be the most beneficial for getting higher green cob yield, green fodder yield and sugar content of sweet corn grains with $50 \%$ saving of nitrogen dose of chemical fertilizers to sweet corn.

\section{References}

Abdul Baki, A.A. and Anderson, J.D. 1973. Vigour determination in soybean seed and multiple criteria. Crop Sci. 13: 630-633.

Aneja, K.R. 2003. Experiments in Microbiology Plant Pathology and Biotechnology. New
Age International, New Delhi. pp. 157-161. Archna, S., Shrivastava, A.K., Asha Gaur, Pushpa Singh, Singh J. and Yadav, R.L. 2008. Nitrogen use efficiency of sugarcane in relation to its BNF potential and population of endophytic diazotrophs at different $\mathrm{N}$ Levels. Plant Growth Regulation. 54 (1): 111.

Bastian, F., Cohen, A., Piccoli, P., Luna, V. and Bottini, R. 1998. Production of indol3acetic acid and gibbrellins $\mathrm{A}_{1}$ and $\mathrm{A}_{3}$ by Acetobacter diazotrophicus. Plant Growth Regulation. 24: 7-11.

Boddey, R., Urquiaga, S., Reis, V. and Dobereiner, J. 1991. Biological nitrogen fixation associated with sugarcane. Plant Soil. 137: 111-117.

Cappuccino, J.G. and Sherman, N. 1987. Microbiology A Laboratory Manual. $2^{\text {nd }}$ Ed. The Benjamin/Cummins Publishing Co., USA., 458p.

Cavalcante, V.A. and Dobereiner, J. 1988. A new acid-tolerant nitrogen-fixing bacterium associated with sugarcane. Plant Soil. 108: 23-31.

Chauhan, H., Sharma, A. and Saini, S. K. 2010. Response of sugarcane to endophytic bacterial inoculation. Indian J. Sugar. Tech. 25(1\&2): 1-4.

Crespo, J.M., Boiardi, J.L. and Luna, M.F. 2011. Mineral phosphate solubilization activity of Gluconacetobacter diazotrophicus under Plimitation and plant root environment. Agric. Sci. 2(1): 16-22.

Dobereiner, J., Reis, V.M., Paula, M.A. and Olivares, F.L. 2000. Endophytic diazotrophs in sugarcane, cereals and tuber plants. In: New Horizons in nitrogen fixation, eds. Palacios, R., Mora, J. and Newton, W. E. pp. 671-676 (Current Plant Science and Biotechnology in Agriculture, Vol. 17).

Dong, Z., Haydrich, M., Bernard, K. and McCully, M.E. 1995. Further evidence that $\mathrm{N}_{2}$ fixing endophytic bacterium from the intercellular spaces of sugarcane stems is Acetobacter diazotrophicus. Appl. Environ. Microbiol. 61: 1843-1846.

Fuentez-Ramirez, L.E., Jiminez-Salgado, T., Abarca-Ocampo, I.R. and CaballeroMellado, J. 1993. Acetobacter 
diazotrophicus, an indolacetic acid producing bacterium isolated from sugarcane cultivars in Mexico. Plant Soil. 154: $145-150$.

Fuentez-Ramirez, L.E., Caballero-Mellado, J., Sepul-Veda, J. and Martinez-Romero, E. 1999. Colonization of sugarcane by Acetobacter diazotrophicus is inhibited by high $\mathrm{N}$ fertilization. FEMS Micro. Ecol. 29: 117-128.

Hema, C. Rao and Savalgi, V.P. 2017. Isolation and screening of nitrogen fixing endophytic bacterium Gluconacetobacter diazotrophicus GdS25. Int. J. Curr. Microbiol. App. Sci. 6(3): 1364-1373.

Indi, D.V., Murumkar, D.R., Nalawade, S.V. and Pawar, S.M. 2017. Influence of Gluconacetobacter diaotrophicus and PSB with graded levels of major nutrients on sugarcane growth, yield and quality parameters. Contemporary Research in India. 7(3): 182-187.

Jackson, M.L. (1973). Soil Chemical Analysis. Prentice Hall of India, New Delhi, India. pp. 134-139.

Murumkar, D.R., Nalawade, S.V., Indi, D.V. and Pawar, S.M. 2017. Response of sugarcane seed plot to microbial inoculation by Gluconacetobacter diazotrophicus and phosphate solubilizing bacteria. Sugar Tech. 19(1): 26-32.

Muthukumarasamy, R., Revathi, G. and Solayappan, A.R. 1994. Biofertilizer - A supplement or substitute for chemical nitrogen for sugarcane crop. Cooperative Sugar. 25: 287-290.

Muthukumarasamy, R., Revathi, G. and Lakshminarasimhan, C. 1999. Influence of $\mathrm{N}$-fertilization on the isolation of Acetobacter diazotrophicus and Herbaspirillum spp. from Indian sugarcane varieties. Biol. Fertil. Soils. 29: 157-164.

Navadkar, P.D. 2015. Effect of co-inoculation of
Gluconacetobacter diazotrophicus and Herbaspirillum seropedicae on growth, yield and nitrogen uptake in sweet corn. M.Sc. (Agri.) thesis submitted to M.P.K.V., Rahuri, M.S., India.

Pandey, S. 2004. Studies on Acetobacter diazotrophicus in sweet corn (Zea mays Saccharata). M.Sc.(Agri.) thesis submitted to M. P. K. V., Rahuri (M. S.), India.

Panse, V.S. and Sukhatme, P.V. 1985. Statistical Methods for Agricultural Workers, ICAR, New Delhi.

Partick, J.R., Chelius, M.K., Iniguez, L., Shawn, M., Kaeppler and Eric, W.T. 2000. Enhanced maize productivity by inoculation with diazotrophic bacteria. $8^{\text {th }}$ International Symposium on Bitrogen Fixation with Non-legumes, Sydney, NSW, December, 2000.

Reis, V.M., Olivares, F.L. and Dobereiner, J. 1994. Improved methodology for isolation of Acetobacter diazotrophicus and confirmation of its habitat. World $J$. Microbiol. Biotech. 10: 101-104.

Riggs, P.J., Chelius, M.K., Iniguez, A.L., Kaeppler, S.M. and Triplett, E.W. 2001. Enhanced maize productivity by inoculation with diazotrophic bacteria. Australian J. Plant Physiol. 28: 829-836.

Stephan, M.P., Oliveria, M., Teixeira, K.R.S., Martinez-Drets, G. and Dobereiner, J. 1991. Physiology and dinitrogen fixation of Acetobacter diazotrophicus. FEMS Microbiol. Lett. 77: 67-72.

Tian, G., Pauls, P., Dong, Z., Reid, L.M. and Tian, L. 2009. Colonization of the nitrogen-fixing bacterium Gluconacetobacter diazotrophicus in a large number of Canadian corn plants. Can. J. Plant Sci. 89: 1009-1016.

\section{How to cite this article:}

Bidarkar, N. A. and Murumkar, D. R. 2020. Response of Sweet Corn to Microbial Inoculation by Gluconacetobacter diazotrophicus. Int.J.Curr.Microbiol.App.Sci. 9(07): 1903-1912. doi: https://doi.org/10.20546/ijcmas.2020.907.217 